\author{
Military Technical College \\ Kobry El-Kobbah, \\ Cairo, Egypt.
}

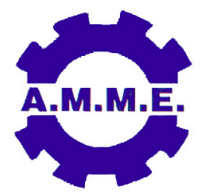

\title{
INVESTIGATION OF CRITICAL LEAN CULTURE CRITERIA FRAMEWORK FOR LEAN TRANSFORMATION
}

\author{
S. A. Salah ${ }^{1}$, N. Sobhi ${ }^{2}$ and N. Ali $^{3}$
}

\begin{abstract}
Many manufacturing companies when implementing lean manufacturing, they only emphasize on lean tools and techniques. They ignored the human factor or more specific they failed to build the right culture. Hence, these companies could not obtain the full benefits of lean manufacturing implementation, and in fact, they are having difficulties sustaining the success attained. This paper provides a theoretical lean culture criteria framework for implementation of lean manufacturing. This framework builds on the literature review that involves major sources of lean manufacturing community and also based on Toyota way culture. This study investigates how the lean culture influences the implementation of lean system in all organizations. The study further explains how an organization can benefit from assessment of their culture by adopting lean culture framework. It is found from the literature review that a number of factors need to be taken into account in order to implement a successful lean system. The framework would enable the organizations to assess their internal culture before implementing lean methodology.
\end{abstract}

\section{KEY WORDS}

Lean manufacturing, organizational culture, lean culture and framework.

\section{ABBREVIATION}

LCCF Lean Culture Criteria Framework.

TPS Toyota production system.

1 Postgraduate Student, Department of Design and Production Engineering, Ain Shams University, Cairo, Egypt.

2 Professor, Department of Design and Production Engineering, Ain Shams University, Cairo, Egypt.

3 Assist. Professor, Department of Design and Production Engineering, Ain Shams University, Cairo, Egypt. 


\section{INTRODUCTION}

The benefits of implementing lean manufacturing in their facilities versus the risks, timing, and resources required for a transformation to lean are still being debated. Once a decision has been made to convert to a lean manufacturing methodology and enthusiasm builds, with a mood for change, then it begins by understanding the products and manufacturing processes, their demand, and the real goals of response time, quality, and minimum working capital investment versus efficiency and utilization. The process of implementing lean manufacturing in your company should be a methodical and disciplined approach. While the transformation process should proceed quickly, the pace of implementation must allow the organization and culture time to adapt to the changes being made. Taking too much time will evaporate the high energy and enthusiasm (Dennis [1]).

David Mann [2] defined the lean culture in a work organization as the sum of all individuals' habits related to the work in the organization. A related way to think of culture is that it's the knowledge of how things are done that an adult needs to stay out of trouble as a member of a group. Culture is the way we do things around here. The importance of the role of organizational culture in the success or failure of a company's ability to successfully implement a new philosophy such as lean manufacturing should not be underestimated.

Organizations should strive for what is considered a healthy organizational culture in order to increase productivity, growth, efficiency and reduce counterproductive behavior and turnover of employees (Wikipedia [3]). The change process such as the implementation of lean manufacturing concepts is not an easy one as it involves a process of implementing new concepts and tools that company will normally require a change in the company's organizational culture. It is important for a company to analyze its organizational culture prior to embarking on the implementation process as it will help it ascertain its initial organizational culture with the aim of determining its strengths and weakness' to help it build a successful strategy of implementation.

The Toyota philosophy forms the back bone of the concepts of lean manufacturing principles that many companies are either starting or have implemented in order to enable them to remain competitive through becoming more efficient. The creation of an organization that has a culture of continuous improvement and achieving results through its various principles and philosophies as described by Liker and Hoseus [4] is important to the Toyota Way model. It is the aim of this research to analyze and determine the criteria relating to the impact of an organization's culture on the concepts of lean manufacturing based on the Toyota Way model.

This paper is intended to investigate of critical lean culture criteria framework for successful implementation of lean methodology based on Toyota culture and the literature survey. 


\section{LITERATURE REVIEW}

\section{Toyota Production System (TPS)}

TPS is not simply a set of tools and concepts, which can be implemented by command and control. Rather it is a fully integrated management and manufacturing philosophy and approach. Organizational culture is an important pillar of the success that Toyota has achieved initially through its TPS principles that developed to the Toyota Way model as shown in Fig. 1. Convis [5] underlines, that the human dimension is the single most important element for success. The TPS is an integrated and interdependent system involving many elements: the tools, the philosophy and management as shown in Fig. 2.

\section{Lean Manufacturing}

Lean manufacturing, lean enterprise, or lean production, often simply, "Lean," is a production practice that considers the expenditure of resources for any goal other than the creation of value for the end customer to be wasteful, and thus a target for elimination. Working from the perspective of the customer who consumes a product or service, "value" is defined as any action or process that a customer would be willing to pay for. Essentially, lean is centered on preserving value with less work. Lean manufacturing is a management philosophy derived mostly from the Toyota Production System (Holweg [6]). TPS is renowned for its focus on reduction of the original Toyota seven wastes to improve overall customer value, but there are varying perspectives on how this is best achieved. The steady growth of Toyota, from a small company to the world's largest automaker has focused attention on how it has achieved this. Lean manufacturing is a variation on the theme of efficiency based on optimizing flow (Bailey [7]). Kronos [8] defines Lean Enterprise as a business system for organizing and managing product development, operations, suppliers, and customer relations. Business and other organizations use lean principles, practices, and tools to create precise customer value, product with higher quality and fewer defects with less human effort, less space, less capital, and less time than the traditional system of mass production.

\section{Definition of Culture}

Bobbi Kimball, [9] state that the word culture is derived from the Latin root colere: to inhabit, to cultivate, or to honor; it generally refers to human activity. Anthropologists define culture as the universal human capacity to classify experiences, to encode and communicate them symbolically through artifacts and behavior. Another definition of culture is a shared set of values, beliefs, and norms. And also culture is a shared language and perspective which helps diverse people to work together in harmony. The same people working under different cultures, even in the same organization, can act in very different ways.

Companies with strong cultures generally perform better than those with weak cultures, but only when the cultural content is appropriate for the organization's environment. Culture should not be so strong that it drives out dissenting values that may form emerging values for the future. Organizations should have adaptive 
cultures so that employees focus on the need for change and support initiatives and leadership that keeps pace with these changes. Organizational culture relates to business ethics in two ways. First, corporate cultures can support ethical values of society, thereby reinforcing ethical conduct. Second, some cultures are so strong that they rob a person's individualism and discourage constructive controversy.

\section{Effect of Existing Organizational Culture}

The organization's culture forms the back bone of the operation of a company and therefore dictates how people work, their attitudes toward work and change, their relationships with each other and management, and the way change is introduced, embraced and tackled. Kaplan and Norton [13] state that the organizational culture of a company is one of the major factors that affect the company's ability to change and that the organizational culture should be tailored in order to support the company's strategy. There are varying organizational cultures from company to company that also include sub cultures that are apparent from department to department and as discussed by Liker and Hoseus [4] the process of achieving strong alignment of a company's goal culture across varying levels of culture is a difficult process to achieve. Ligus [14] stated that the implementation process of lean will be difficult without the right existing of organizational culture. Company with a strong culture of being controlling and bureaucratic will have difficulty in developing a lean culture. Kaplan and Norton [13] states that the culture of the organization is consider a barrier or an enabler to the change for successful lean implementation.

\section{Toyota Culture}

The foundation of Toyota's culture is deeply rooted in many of Japan's work philosophies and practices. Japan's workforce shares a sense of equality; desire to improve from continued education, the desire to have lifelong employment and the centering of daily living around work. Toyota's specific approach to work is heavily influenced by the concept of "Hitozukuri" (the process of educating people) and "Monozukuri" (process of making or creating things) (Cho [15]). Toyota believes that "Hitozukuri" is the foundation for "Monozukuri" which is consistent with TPS. Liker \& Hoseus [16] described the importance of trust in Toyota's culture as distinctive. They describe that the trust in the firm has not come through words; rather through policy and daily interaction among members, which eventually encouraged them to feel a part of Toyota's family. Toyota believes that a work environment should make full use of their workers capabilities. Workers should not have to struggle with operations filled with waste or be treated without consideration. A work environment that would allow workers to display their full capabilities would be a foundation of human respect of the highest order (Shook[17]).

Toyota's culture can also be described as a mutual understanding between people and the work they perform. Without a correct understanding of people, operations in the manufacturing system will not function. Workers will not be motivated to eliminate waste or take part in the improvements. Thus, Toyota's human system is the most complicated, most powerful, most resourceful and the most difficult element in TPS. Although it is popular to share the view that people are the most important asset of a company (Liker and Hoseus [4]). This knowledge of the role of Toyota's history and 


\section{Toyota Production System House ${ }^{x}$}

\section{Level Loading: Foundational Though Not Implemented First}

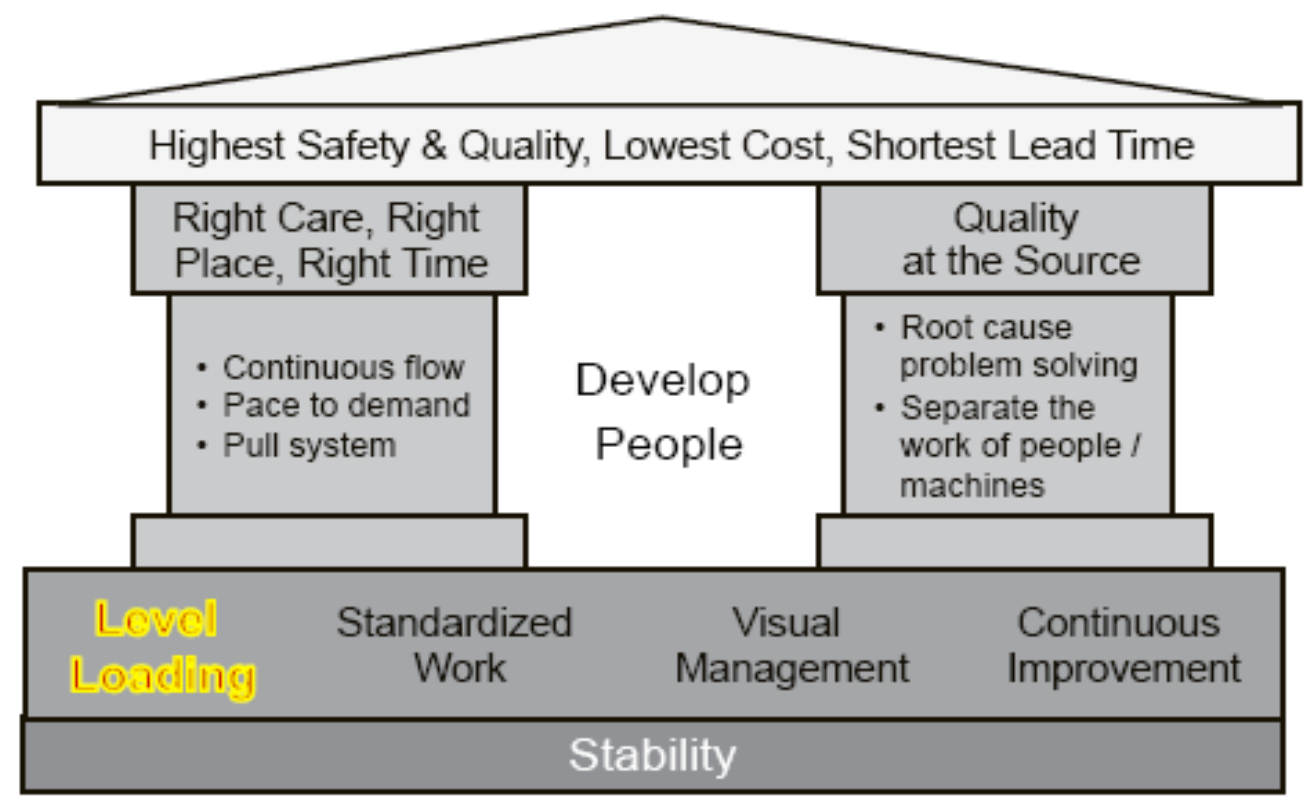

Fig. 1. Toyota production system principles ( Convis [5]).

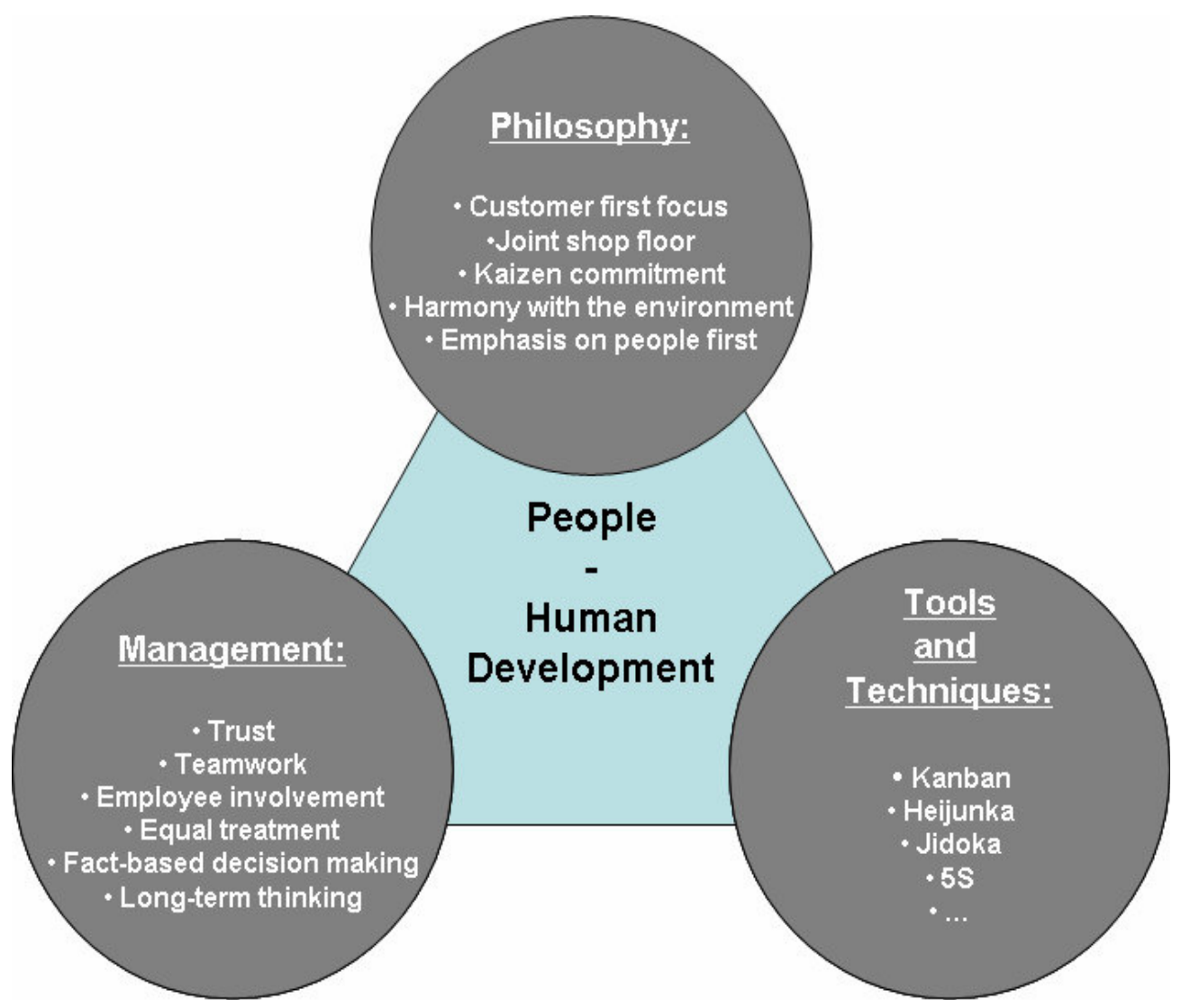

Fig. 2. The main elements of Toyota Production System (Convis [5]). 
practices is important to understand the role of organizational culture for successful lean transformations.

Marksberry et al. [18] describe that in Toyota, every improvement tool such as problem solving, process improvement and machine/worker connection is according to the proper techniques or procedures. It is made a mandatory procedure and people at every level must adhere to the assigned procedures. Many traits and attitudes have driven Toyota to succeed and made Toyota's workers different from other workers around the globe. Some of these prominent traits are a sense of fairness at work, willingness to improve, security at work as Toyota follow a lifetime employment policy, no barriers between senior management and shop floor worker and workers have the chance to be promoted to managerial positions. Toyota culture is continuous improvement or scientific experiment. The other most common elements are the long term thinking and the emphasis on people (respect, involvement). Within these three main features there are several others to mention. Because perhaps the book by Liker and Hoseus [4] the one which provides the most complete picture of the Toyota culture, as shown in Table 1.

Portia Tung [19] introduces the principles of lean management of "Toyota Way" as listed below:

- Heijunka: smooth the workload.

- Standardize the work and use reliable, known technology.

- Use Visual Control so no problems are hidden.

- Flow where you can, pull if you must.

- Jidoka: build a culture of stopping to fix problems, to get quality right the first time.

- Genchi Genbutsu: go and see for yourself to thoroughly understand the situation.

- Grow leaders who thoroughly understand the work, live the philosophy and teach it.

- Nemawashi: make decisions slowly by consensus, thoroughly considering all options.

- Leader Standard Work and daily accountability to improve processes.

- Leadership discipline.

- Develop exceptional teams who follow your company's philosophy.

- Understand customer value and let it drive all your actions.

- Become a learning organization through relentless reflection.

- ("Hansei") and continuous improvement ("Kaizen").

- Respect your extended network of partners and suppliers by challenging them.

\section{Lean Culture}

Tempel [20] added that the top management presence and availability on the shop floor is one of the most critical points during the lean rollout. Therefore a lean culture is characterized by emphasis on people first, trust, strong customer orientation and the joint shop floor. A related way to think of culture is that it's the knowledge of how things are done that an adult needs to stay out of trouble as a member of a group. One of the interesting things about culture is that for group members, culture is 
Table 1. Features of the Toyota culture (Liker et. al [4]).

\begin{tabular}{|c|c|c|c|c|c|}
\hline No & Toyota Culture & No & Toyota Culture & No & Toyota Culture \\
\hline 1 & $\begin{array}{c}\text { Continuous attention } \\
\text { toward the external } \\
\text { environment }\end{array}$ & 13 & $\begin{array}{c}\text { Process-thinking in } \\
\text { decision making and } \\
\text { problem solving }\end{array}$ & 25 & $\begin{array}{c}\text { Searching for } \\
\text { development } \\
\text { opportunities }\end{array}$ \\
\hline 2 & $\begin{array}{c}\text { Two ways, open } \\
\text { communication channels }\end{array}$ & 14 & Employee involvement & 26 & $\begin{array}{c}\text { Regular information } \\
\text { and knowledge sharing }\end{array}$ \\
\hline 3 & $\begin{array}{c}\text { Learning from } \\
\text { experience }\end{array}$ & 15 & Personal involvement & 27 & Employee development \\
\hline 4 & $\begin{array}{c}\text { Treating employees as } \\
\text { partners }\end{array}$ & 16 & Employee suggestions & 28 & Constructive critique \\
\hline 5 & Cooperation & 17 & Support & 29 & Discussions \\
\hline 6 & Human focus & 18 & Responsibility & 30 & Rights to feedback \\
\hline 7 & Tidiness & 19 & Trainer leaders & 31 & Visual management \\
\hline 8 & Conflict acceptance & 20 & Forwarding goals & 32 & Finding root causes \\
\hline 9 & Commitment, loyalty & 21 & Respect & 33 & Long term thinking \\
\hline 10 & Customer focus & 22 & Consistency & 34 & Self critique \\
\hline 11 & Innovative spirit & 23 & Rewarding guidance & 35 & Minimizing losses \\
\hline 12 & Trust, sincerity & 24 & Tolerating failures & & \\
\hline
\end{tabular}

invisible. It's the things that are "given," or "the way we do things around here." It's typical not to question this kind of thing, or even to realize there are alternatives to it. It's easily possible to "see" work culture in a production environment by asking basic questions about common practices (Liker\& Hoseus [21]). WMEP [22] drive five ways to promote a lean culture in your organization:

- Focus on the customer: The goal of lean is to provide the customer exactly the right product, on time and without flaws. Develop collaborative relationships with your customers in order to get ideas for improvements and cost-savings.

- Communicate a clear vision for the company: Lean is the path to achieving business objectives, and it requires on-going executive support. A successful lean culture requires a strong commitment and investment from company management to make sure employees feel their input is valued and encouraged. Because lean culture starts at the top, we focused on the leadership team and changed the way we interacted with employees in order to enhance employee engagement.

- Establish performance metrics and share them with everyone: A critical step in developing lean culture involved a lean assessment, which provides a snapshot of where the company stands on day one. Performance metrics were established in the areas of quality, cost, safety and delivery. These metrics are tracked and posted for everyone to see to encourage participation and suggestions for improvements.

- Provide Lean training: The best way to learn is hands-on, and a core method used to implement lean is the Kaizen blitz. Kaizen blitzes are intensive one- or two-day sessions focused on applying lean principles. Kaizen events actually 
redesign processes and deliver results; it is a key way for anyone learns to understand the practice of lean.

- Live Lean: Sustaining lean practices requires continual effort and commitment. Training is repeated every two years for new people and to refresh employees to help them continually think about eliminating non-value-added activities.

\section{RESEARCH DESIGN AND METHODOLOGY}

This study will investigate the critical lean culture criteria Framework for successfully implement lean methodology in manufacturing companies. Lean culture criteria are collected from literature review based on main core principles criteria of the Toyota Way culture and other companies leading in lean transformation. The validation of those criteria is carried out by using survey method for the experts in lean culture in the most successful companies.

\section{Lean Culture Criteria Framework (LCCF)}

LCCF helps organizations to look more closely to the culture qualitatively and to quantify it by measuring the certain criteria, which one believed to relate directly to lean and to know if the culture is healthy enough to cope with lean by knowing the weakness and strength of the culture. Furthermore, LCCF would help organizations to understand the factors that make their culture and to see if these factors could be aligned with lean principles. It is very important for any organization to start focusing on improving the mutual respect and employee's involvement cultures that's help to facilitate and speed up the improving in all lean culture criteria and intend lean implementation.

This framework is to allow leaders to know how far their organization is from lean culture. LCCF may be suitable for both companies that desire to implement lean and for those who have failed in implementing lean. LCCF consists of seven main criteria namely continuous improvement, processed focused, mutual respect and trust, employee's involvement, consistency, mission and adaptability as shown in Fig. 3. Each of these main culture criteria has sub- culture criteria that would enable organizations to know their attitudes towards lean. The culture's main criteria in the proposed framework are believed to be the most critical factors in Toyota's culture. If these elements are addressed properly, then the organization can successfully implement the lean system and eventually sustain it.

\section{Lean Culture Criteria Framework Construction}

The developed lean culture criteria framework encompasses seven main criteria and each main criterion is divided into few sub-criteria as follows:

\section{Continuous improvement}

Continuous improvement encompasses six sub-criteria; root cause problem solving, leader standard work, leaders go to Gemba walk, daily accountability process, visual controls, and level out the work load. 


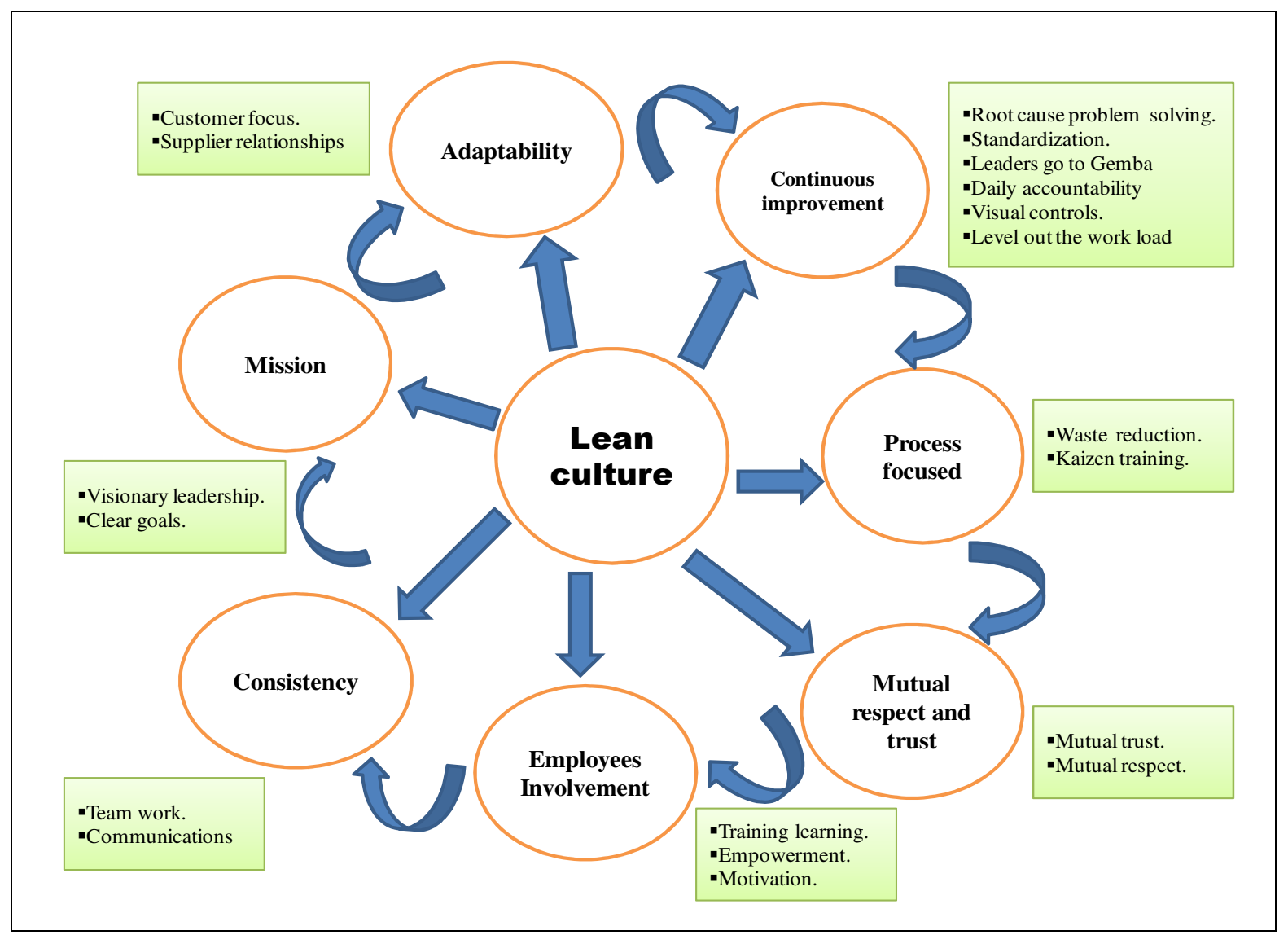

Fig. 3. Lean Culture Criteria Framework.

\section{a) Root cause problem solving}

The concept of effective problem identification and solving within the company's working environment has an important role to play in the creation of an organization culture that promotes innovation and continuous improvement. The concept of problem solving forms one of the four main principles that incorporated in the 4P model of the Toyota Way. Liker and Hoseus [4] state that the core of the Toyota Way is the development of employees that are willing and competent to continually improve the way work is done. It is therefore important that the employees of the company are trained and competent in the tools of problem solving with the problems being timeously identified, fine the root cause and solved in order for the company to be continuously improving.

\section{b) Leader Standard Work}

The concept of standard work is important within a company as the process of how the work place operations needs to be documented in a way that firstly is reflective of how the process is performed and secondly in a way that employees can be effectively trained. Pieterse [23] states that the documenting of standard tasks can help to prevent operational mistakes, accidents and minimize the recurrence of defect products while the standardization of a process also enables it to be improved by it being documented. The employees performing the everyday operations must realize that they are the process owners and that they have the responsibility to continually revise the standard processes with a view of improving them. 


\section{c) Leaders go to Gemba walk}

Gemba walk is very important culture leads to rapid improvement, SAM GRIER [24] states that Gemba (the real place) walk performed one or more times a day is a zero cost, high impact practice that will give you a better understanding of the work in progress and the people who do the work. Quickly you will find your Gemba walk to be the most valuable part of your day. If you seek solutions to problems that need to be fixed, go to Gemba, go to where the work is performed and observe and engage with those who do it. The purpose is to observe what is going on in the workplace. It is important for leaders to gather information on any current problems so they can be resolved and to engage with workers as they do they work.

\section{d) Daily accountability process}

A daily accountability process is important in lean culture. David Mann [2] state that daily accountability process considered the principal element of the lean management system. It provides the steering wheel, that is, the task assignments made by the meeting leader for what improvements will be worked on. It also provides the throttle, or the due date and resources for the improvement task. The daily accountability process takes place as an interlocking set of three brief, structured, daily meetings. Each of these meetings is an explicit example of lean management's focus on comparison of expected and actual.

\section{e) Visual controls}

David Mann [2] state that visual controls are powerful contributors to lean management. Visuals reflect the human scale of production activity and process focus. They connect people to their processes, and at the same time reflect adherence to the process or its lack. Visual controls help transform the abstract concept of discipline in lean management into directly observable, concrete practices. Actual versus expected moves from the realm of an idea to easily interpreted visual tracking tools. Visual controls are the basis for comparing actual versus expected performance, they do not make the comparison but they make the comparison possible.

\section{f) Level out the work load}

Level out the work load is important in lean culture. David McBride [25] explains that many companies today are working toward the ultimate lean goal of continuous or one-piece flow. They want to be able to make just what the customer wants when they want it. Customers' orders vary from month to month; creating uneven production scheduling build-to-order companies will be building huge quantities, paying overtime, and stressing their people and equipment one week, but then sending them home the next due to light orders. This environment can also create large amounts of inventory, hidden problems and poorer quality. This is the Toyota concept of heijunka, leveling out the work schedule. Heijunka is the leveling of production by both volume and product mix.

\section{Process focused}

Process focused has a significant effect on the organizational culture of the company it is help leaders and employees in using a set of tools for improving the way of work done. Process focused enable the organization to define all kind waste and drive 
way to minimize its. Process focused divided into two sub- criteria; waste reduction and Kaizen training.

\section{a) Waste reduction}

Waste reduction is very important in lean culture. Waste reduction means reduce defects and unnecessary physical wastage, including excess use of raw material inputs, preventable defects, costs associated with reprocessing defective items, and unnecessary product characteristics which are not required by customers.

\section{b) Kaizen training}

It is important for a company to have the ability to continuous improve the process by using Kaizen. The underlying of Kaizen is that it makes employees become aware that by using their skills to improve a process, results in the business becoming more successful, which lends itself to meaning more job security for the employee. Kaizen requires bringing employees together to look at their jobs, sections, and processes, to realize changes that will help performance. In order to implement Kaizen, a team needs to be set up to look at a workplace (Fujitsu [26]).

\section{Mutual respect and trust}

Respecting for people means in Toyota, knowing how the leaders lead and how the system works and finally understand how Toyota have achieved and sustained the continuous improvement in culture. Mutual respect and trust encompasses tow subcriteria; mutual respect and mutual trust.

\section{a) Mutual trust}

The level of trust that exists between a company's management and its employees has a significant effect on the organizational culture of the company as it will help determine how they interact with each other. It is apparent that if low levels of trust were to exist within a company then it would be difficult for the employees to work openly together. Swanepoel et al [27] states that trust is the cornerstone of employment relations.

Liker and Hoseus [4] state that if the company's employees do not trust their employers they would be reluctant to highlight problems and that a culture would therefore be created where employees would feel that is safer to actually hide problems.

\section{b) Mutual respect}

Mutual respect has a significant effect on the organizational culture of the company, it is help employees to become deep felt for the organization and give freely of their creative abilities and do his best to improve the processes, decreases the waste and absenteeism. It is therefore important for a company that there is a sufficient level of mutual respect between the management and employees that promotes a transparent working environment where there is mutual respect between employees.

\section{Employees involvement}

Apostolos [28] defined employee involvement as that every employee is regarded as a unique human being, not just a cog in a machine, and each employee is involved 
in helping the organization to meet its goals. Each employee's input is solicited and valued by his management. Employees and management recognize that each employee is involved in running the business. Employees Involvement consists of three sub- criteria; training and learning, empowerment and motivation.

\section{a) Training and Learning}

Training and learning are important for development programmes in any company, it is important also to include the training with a certain element of coaching and mentoring. Johnson and Scholes [29] state that it is important from the time an employee first joins a company that there is an effective training and development programme that includes the induction programme and training on competencies required for the position while also ensuring the employee is properly developed fundamental skills and values. This will form part of the process of incorporating the new employee into the organizational culture of the company. Swanepoel, et al, [27] state that it is important for a company to ensures that its employee training and development programmes are aligned to the company's strategy and structure. It is important for organization to focuses on upgrading workers' skills and knowledge to improve efficiency and customer service.

\section{b) Empowerment}

Employee empowerment is a somewhat different concept, it means that in addition to involving employees in running the business, employees and management recognize that many problems or obstacles to achieving organizational goals can be identified and solved by employees. Employee empowerment means that management recognizes this ability, and provides employees with the tools and authority required to continuously improve their performance. The management states its expectations about employees recognizing and solving problems, and empowers them to do so. Empowerment also requires management to take risks by turning over some control of the organization to the employees. Management must appreciate that relinquishing control to the effective and skilled employees will result in a more productive organization with better teamwork and faster problem resolution.

\section{c) Motivation}

The level of success of a company in achieving its goals and targets through its employees and teams is affected by the level of motivation of its employees. The level of motivation of an employee can be affected by various factors such as personal circumstances, to the environment that exists within the company. The environment that exists within the company is influenced by the manager's ability to understand their employees and to also understand what motivates them to achieve their goals while also understanding that each employee is different (Schultz et al, [30]).

\section{Consistency}

Consistency is very important culture in lean management. Consistency provides a central source of integration, coordination and control (Denison [31]). It is found to be another strong factor in Toyota's culture, Toyota works hard to instill a team work sprit and encourage people to work with different department in order to come to a 
shared agreement. Consistency consists of two sub- criteria; Team work and communication.

\section{a) Team work}

The successful use of teams in the work place has enabled companies to achieve benefits in terms of achieving goals and creating an environment that benefits the employees working within the team concept. Schultz et al [30] defines a team as a group of people that work together in a cooperative way to achieve an outcome. Effectively managed teams can enable the company to achieve greater performance levels and increasing the company's effectiveness.

Liker and Hoseus [4] state that one of the main ways to transmit the Toyota Way culture is through the basic team concept that helps provide the roles of supporting the individual doing their work and solving problems in order to improve how their work is done.

\section{b) Communications}

The effectiveness of the communication that exists within the company plays a major binding role. Communication has an influence on everyday activities that occur in the workplace thus influencing the organizational culture that exists in the company. Schultz et al [30] states that the communication that exists within a company allows employees to be able to coordinate actions and to share information while also helping to satisfy the social needs of the employees. The communication that exists needs to be able to transcend the levels of hierarchy in the organization to ensure that employees can get feedback on problems that were raised while team members can effectively share feeling while resolving conflicts and problems.

\section{Mission}

Mission is principle in lean culture, it enable leaders to communicate the organization's vision for the future and focuses on the leadership team and changed the way we interacted with employees. Mission divided into two sub-criteria; visionary leadership and clear goals.

\section{a) Visionary leadership}

Leaders identify for the major barriers that need to be overcome in order to achieve the organization vision. Leaders must clarify the role and responsibility for each employee and provides valuable, timely information about changes that are going on. Leaders allow open two-way vertical and horizontal communications. Leaders must clarify vision, mission and values of organization. Moreover, goals and metrics must be transparent, aligned and interconnected from the organization's strategic plan down to departmental team and individual levels. Ensure that every employee from top to bottom understands what the organization is looking to accomplish and how their individual role contributes to the achievement of that vision. Growth Con [32] state that your mission statement should define who your primary customers are, identify the products and services you produce, and describe the geographical location in which you operate. 


\section{b) Clear goals}

Every company should have a clear goal in mind. Individual teams must understand what that goal is, and know their role both individually and as a group accomplishing it. To accomplish your goal, the team must have the right tools. At the beginning of the project, create a list of everything you'll need in terms of both staffing and resources. A goal is a simple but powerful way to motivate people and communicate priorities. Leaders have demonstrated the power of using specific, challenging goals to improve performance and cut costs.

\section{Adaptability}

Adaptability is very important in lean culture. Organizations hold a system of norms and beliefs that support the organization's capacity to receive, interpret, and translate signals from its environment into internal behavioral changes that increase its chances for survival, growth and development". Toyota is an adaptable organization as it found to be responsive to the fluctuations in market. Adaptability divided into two sub- criteria; Customer focus and supplier relationships.

\section{a) Customer focus}

Leaders must focus in defining the customer requirements to provide the customer exactly the right product, on time and without flaws in order to increase the customer satisfaction levels. Organization must pay attention to take the time to understand how value is actually delivered to customers in order to help to break down functional silos and drive true alignment. Perceived quality includes ease and timeliness of the processes, clarity and accessibility of information, professional customer service, and ability to access information quickly and easily. The ultimate goal of collecting customer feedback should not be just to measure customer satisfaction, but rather to gain insights into customer expectations and experiences, and to use those insights to set appropriate organizational goals and to identify opportunities for improvement.

\section{b) supplier relationships}

Establish a good relationship with supplier is important in lean culture. Organization must establish system to collects periodic feedback from partners and suppliers and organize a regular meeting with partners and suppliers monthly and also leaders foster regular communication channel within and between work cells and also outside your department to continuous improve the quality of the product.

\section{Questionnaire Construction}

This study is aimed to investigate the critical lean culture criteria for successful implementation of lean principles. The lean culture is based on Toyota's culture. This study developed a questionnaire which is suitable for measuring the importance of the selected lean culture criteria which present in the above framework.

Questionnaire is constructed such that each main culture is divided into number of sub- culture criteria as shown in Appendix A. Questionnaire is designed to ask about the degree of importance of each sub- culture criteria in implementation of lean methodology. We believe that all important lean culture criteria are included in this questionnaire. All questions carry the same weight or importance. Each question is answered along a continuum that ranges from "critical in lean" behavior to not 
important in lean behavior on the scale rating. Thus, by answering each question one evaluates the critical lean culture criteria. By combining performance on subprinciples criteria, one assesses conformance to the main principles.

\section{Format of Questionnaire}

The method of data collection is the questionnaire method. The questionnaire was designed by the researcher with the aim of ensuring the format of the questionnaire was aligned to the desired output of ensuring that the selected lean culture criteria in our framework are critical for implementation of lean methodology in manufacturing company. The method of the questionnaire was chosen with the aim of obtaining data in order to determine the degree of importance of the selected lean culture criteria through analyzing the results of the specific questions asked. The questionnaires were spread out for ten companies from the most successful manufacturing companies in lean implementation.

\section{RESULTS AND DISCUSSION}

The proposed lean culture criteria framework has been developed based on Toyota's culture. In order to know if the organizational culture is helping lean transformation, seven main criteria are developed to enable understanding it in a better way. These main criteria are developed from Toyota Way, which is believed to be helpful in understanding or creating the lean culture. The seven main criteria describing characteristics of a lean culture (continuous improvement, processed focused, mutual respect and trust, employee's involvement, consistency, mission, adaptability) are believed to have great impact on the core organizational culture. This framework may help companies to face their basic underlying assumption and to know how far they are from a lean culture.

The results of the survey are shown in Fig. 4. Along the column chart there can be seen the average values of each lean culture criteria for ten successful Production Companies are above 4 on the Likert-scale. The chart shows that all selected lean culture criteria are critical in successful implementation of lean methodology.

\section{CONCLUSION}

Many companies ignore the lean culture when implementing lean manufacturing, they only emphasize on lean tools and techniques. Hence, these companies could not obtain the full benefits of lean manufacturing implementation and they are having difficulties in sustaining the success attained. This paper provides a theoretical framework for lean culture which built on the Toyota culture and other lean successful companies. This framework shows seven vital lean culture criteria that companies must pay attention to, these criteria are: continuous improvement, process focused, mutual respect and trust, employee's involvement, consistency, mission, adaptability. This is apparent in the results achieved from the questionnaire survey which designed for this research study, also indicates that it was a reliable and valid method for the research study for manufacturing sectors. 


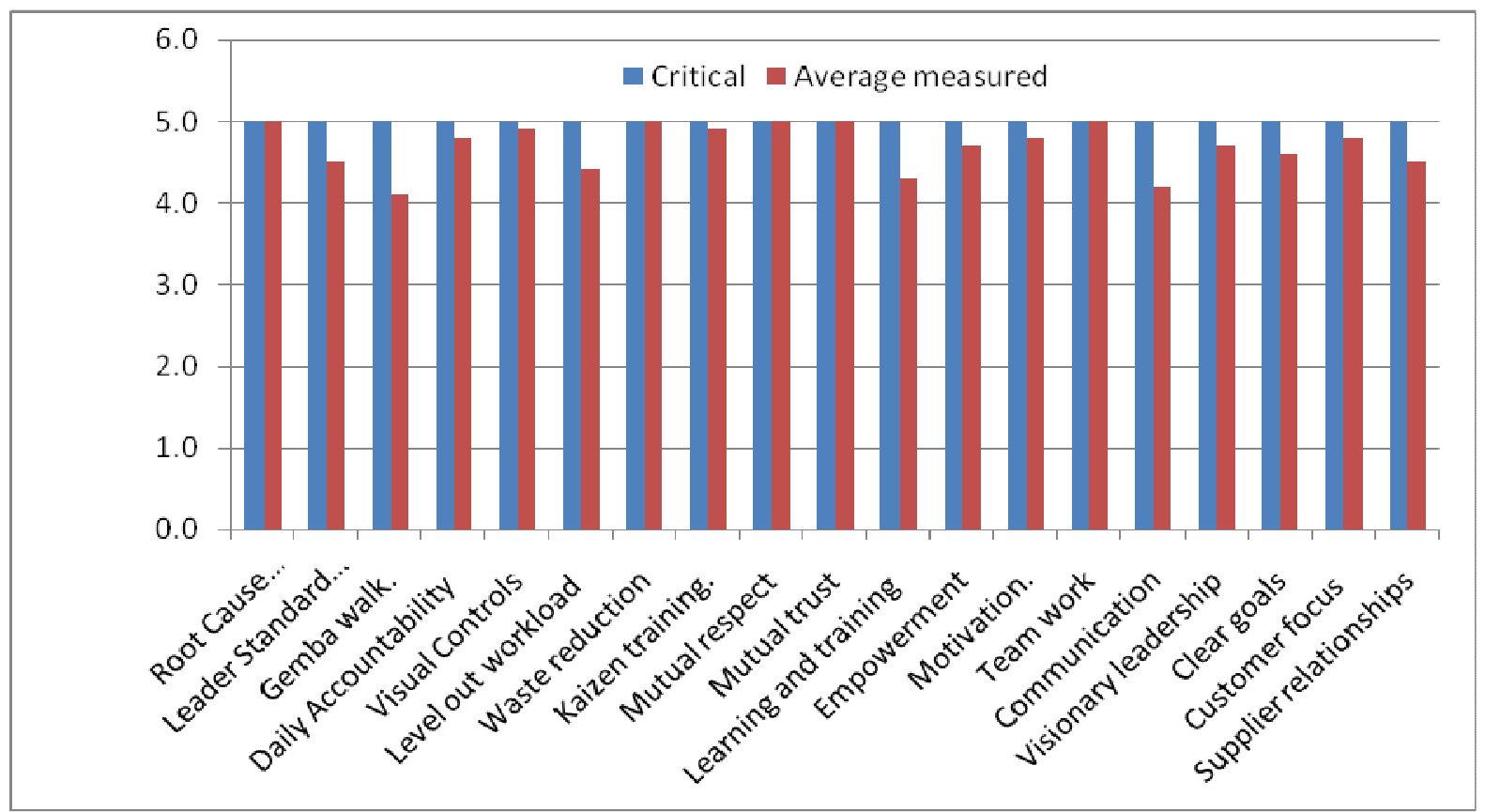

Fig. 4. The average degree of importance of each lean culture criterion.

\section{REFERENCES}

[1] Dennis P. Hobbs \& J. Ross Publishing, "Lean Manufacturing Implementation: A Complete Execution Manual for Any Size Manufacturer", USA, 2004.

[2] David Mann, "Creating a Lean Culture, tools to sustain lean conversion", Productivity Press, a division of The Kraus Organization Limited, New York, 2005.

[3] Wikipedia, "Lean manufacturing" Wikipedia, the free encyclopedia, 2012. http://en.wikipedia.org/w/index.

[4] Liker, J.K. and Hoseus, M., "Toyota culture: The heart and soul of the Toyota way", New York, MGraw-Hill, NY, 2008.

[5] Convis, Gray, "Role of management in a lean manufacturing environment; in: Learning to think lean", 2001.

[6] Holweg, Matthias, "The genealogy of lean production". Journal of Operations Management, 25 (2): 420-437. doi:10.1016/j.jom. 2006.

[7] Bailey, David, "Automotive News calls Toyota world No 1 car maker". http://www.reuters.com/article/businessNews/idUSN. April 2008.

[8] Kronos Incorporated, "Applying Lean principles to improve workforce management" Billerica Road 297, Chelmsford, MA 01824, www. kronos.com., 2009.

[9] Bobbi Kimball, R.N., M.B.A, "Cultural Transformation in Health Care" A white paper that describes the complex nature of organizational culture and its role in health care organizations, 2005.

[10] Steel, R., "Culture and complexity-Organizations \& People", Vol 7, no. 2, 2004.

[11] Ravasi, D., Schultz, M., "Responding to organizational identity threats: exploring the role of organizational culture", Academy of Management Journal, Vol.49, No.3, pp.433-458, 2006.

[12] Steven L. McShane, “Organizational culture”, Chapter Sixteen, 2000. 
[13] Kaplan, R.S., \& Norton, D.P. "Organization Capital and Managing change to reduce resistance", Harvard Business School Publishing Corporation, 2005.

[14] Ligus, R.G. "Organizational Development: The missing link in lean transformations", Rockford Consulting Group, 2006.

[15] Cho, F., "Mono-zukuri and Hito-zukuri", Lecture on Presented at Toyota Vietnam Foundation, September 13, 2005.

[16] Liker, J. K., \& Hoseus, M., "Human Resource Development in Toyota Culture", International Journal of Human Resources Development and Management, 10 (1), 34-50, 2010.

[17] Shook, J., "Toyota's secret”, MIT Sloan Management Review, Vol. 50, pp. 30-3, 2009.

[18] Marksberry, P., Badurdeen, F., \& Magin, M. A.. "An investigation of Toyota's social-technical systems in production leveling", Journal of Manufacturing Technology Management, 22 (5), 604-620, 2011.

[19] Portia Tung, "The Toyota Way Principles of Lean Management", 2009, http://www.agilecoach.net.

[20] Tempel, Frank, Holländer, Martina, "Get rid of waste through team harmony", Landsberg, Germany, 2001.

[21] Liker, J.K., "Toyota Way", McGraw-Hill, New York, NY, 2004.

[22] WMEP, (promoting lean culture in your organization), Wisconsin manufacturing extension partnership, 2012. http://www.wmep.org/staff-partners.

[23] Pieterse, K., "Leaning the South African way", 2nd ed., Trilean Publishing, 2007.

[24] SAM GRIER, "Why Management Should Go to Gemba", IT Managers Inbox, 2013. http://itmanagersinbox.com/1488/the-gemba-walk-a-tool-it-managementand-leadership/.

[25] David McBride, "Heijunka: Leveling the load", reliable plant, http://www.reliableplant.com/Read/14245/heijunka, 2013.

[26] Fujitsu PRO-NES, "Power of KAIZEN Activities at workshop", (Asia) Pte. Ltd. All rights reserved, 2005.

[27] Swanepoel, B., Eramus,B., Van Wyk,M \& Schenk,H., "South African human resource management", 3rd ed. Juta \& Co Ltd., 2003.

[28] Apostolos Apostolou, 2000. "Employee involvement", INNOREGIO: dissemination of innovation and knowledge management techniques, D. of Production Engineering \& Management Technical University of Crete.

[29] Johnson, G. \& Scholes, K., "Exploring corporate strategy" 6th ed. Prentice Hall, 2002.

[30] Schultz, S., Bagraim, J., Potgieter, T., Viedge, C. \& Werner, A. 2003.

[31] Denison, D. R., "Organizational culture: can it be a key lever for driving organizational change?", In S. Cartwright, \& C. Cooper (Eds.), the Handbook of Organizational Culture. London: John Wiley \& Sons, 2000.

[32] Entrepreneur's GrowthCon, "Mission Statement", Entrepreneur, 2014. http://www.entrepreneur.com/encyclopedia/mission-statement. 


\section{Appendix A}

Degree of importance of lean culture criteria questionnaire

\begin{tabular}{|l|l|}
\hline COMPANY & \\
\hline DATE & \\
\hline POSITION & \\
\hline
\end{tabular}

Please note the following:

Please answer all questions openly and honestly to ensure accurate results by placing $X$ on the scale rating which feel that happened in your organization.

Please indicate your level of importance to the following statements using this scale and take your time for accurate responses:

Please click on a number from 1 to 5 for each statement below:

\begin{tabular}{|c|c|c|c|c|}
\hline 1 & 2 & 3 & 4 & 5 \\
\hline Not important & Undecided & Important & Strongly important & Critical \\
\hline
\end{tabular}

\begin{tabular}{|c|c|c|c|c|c|c|}
\hline & Lean Culture Criteria & \multicolumn{5}{|c|}{ scale } \\
\hline & & 1 & 2 & 3 & & 5 \\
\hline A & Continuous improvement & & & & & \\
\hline A1 & Root Cause Problem Solving & & & & & \\
\hline A2 & Leader Standard Work & & & & & \\
\hline A3 & Leaders go to Gemba walk. (walk to the site of problem) & & & & & \\
\hline A4 & Daily Accountability Process & & & & & \\
\hline A5 & Visual Controls & & & & & \\
\hline A6 & Level out the workload & & & & & \\
\hline $\mathrm{B}$ & Process focused & & & & & \\
\hline B1 & Waste reduction & & & & & \\
\hline B2 & Kaizen training. & & & & & \\
\hline $\mathrm{C}$ & Mutual respect and trust & & & & & \\
\hline C1 & Mutual respect & & & & & \\
\hline $\mathrm{C} 2$ & Mutual trust & & & & & \\
\hline $\mathrm{D}$ & Employees Involvement & & & & & \\
\hline D1 & Learning and training & & & & & \\
\hline D2 & Empowerment & & & & & \\
\hline D3 & Motivation. & & & & & \\
\hline $\mathrm{E}$ & Consistency & & & & & \\
\hline E1 & Team work & & & & & \\
\hline E2 & Communication & & & & & \\
\hline $\mathrm{F}$ & Mission & & & & & \\
\hline F1 & Visionary leadership & & & & & \\
\hline F2 & Clear goals & & & & & \\
\hline G & Adaptability & & & & & \\
\hline G1 & Customer focus & & & & & \\
\hline G2 & Supplier relationships & & & & & \\
\hline
\end{tabular}

